C O L A B O R A Ç $\tilde{A}$ O

\title{
OPERACIÓN ARAÑA: REFLECTIONS ON HOW A PERFORMATIVE INTERVENTION IN BUENOS AIRES'S SUBWAY SYSTEM CAN HELP RETHINK FEMINIST ACTIVISM
}

Operación Arańa: reflexóes sobre como uma intervenção performática no metrô de Buenos Aires pode ajudar a repensar o ativismo feminista

Operación Araña: reflexiones sobre cómo una intervención performática en el subterráneo de Buenos Aires puede ayudar a repensar el activismo feminista

MARIELA MÉNDEZ ${ }^{1 *}$

DOI: http://dx.doi.org/10.1590/S2178-14942020000200004

'University of Richmond - Richmond, USA

*Associate Professor Latin American, Latino, and Iberian Studies \& Women, Gender, and Sexuality Studies.

(D) https://orcid.org/0000-0003-0344-7548

Article received on January 1, 2020 and approved for publication on March 22, 2020. 


\begin{abstract}
On July 31, 2018, Buenos Aires's subway system was overtaken by a public intervention under the name "Operación Araña," co-organized by Ni Una Menos — a feminist social movement focused on gender violence - , the Campaign for the Right to Legal, Safe, and Free Abortion, unionized metro workers, and more than seventy organizations, with the overall intention of affirming women's autonomy and calling attention to several social issues with direct impact on their lives. This study weaves a series of reflections on some of the specific features of the Operación Araña intervention that can shed light on how and why the new feminist wave in Argentina has gained such momentum while gauging its impact on redefining what we understand as activism. Drawing from Judith Butler's notions on the performative political potential of the assembly (Notes Toward a Performative Theory of Assembly, 2015), this article unveils the various forms of embodied resistance staged in the public space by this new surge of activists, popularly called the "green tide" after the color identifying the Campaign for the Right to Legal, Safe, and Free Abortion. In claiming a unique and radical performative space wherein to exercise agency and display new forms of organization, the green tide also has by the same token laid claim to a reconfigured public space conducive to new forms of sociality and the preservation of all lives.
\end{abstract}

KEYWORDS: Green tide; Campaign for the Right to Legal, Safe, and Free Abortion; Collective performance; Activism.

\title{
RESUMO
}

No 31 de julho de 2018, o metrô de Buenos Aires foi tomado pela intervenção performática Operación Araña, organizada pelo movimento social feminista focado na violência de género Ni una Menos, uma campanha pelo aborto legal, livre e gratuito por membros do sindicato do metrô, e mais de 70 organizações, com os intuitos de garantir a autonomia das mulheres e tornar visiveis questões sociais que têm impacto direto sobre suas vidas. 0 ensaio entrelaça um conjunto de reflexões acerca de algumas das características da intervenção a fim de esclarecer como e por que essa nova onda feminista tem alcançado grande ímpeto a ponto de redefinir o próprio conceito de ativismo. Inspirado nas noções de Judith Butler sobre o potencial político performativo da assembleia (Notes Toward a Performative Theory of Assembly, 2015), o ensaio expõe as diferentes formas de resistência encarnadas nos corpos dessa nova onda de ativistas que ocuparam o espaço público. Ao reclamar um espaço radical performativo no qual podem exercer agência e desenvolver novas formas de organização, a maré verde tem conseguido exigir uma reconfiguração do espaço público capaz de levar a novas formas de sociabilidade e à preservação de todas as vidas.

PALAVRAS-CHAVE: Maré verde; Campanha pelo Aborto Legal, Seguro e Gratuito; Performance coletiva; Ativismo.

\section{RESUMEN}

El 31 de julio de 2018, el subte de Buenos Aires fue tomado por una intervención pública bajo el nombre de "Operación Araña", coorganizada por Ni Una Menos — un movimiento social feminista enfocado en la violencia de género — la Campaña por el Aborto Legal, Seguro y Gratuito, miembros del sindicato del metro y más de setenta organizaciones, con la intención de afirmar la autonomía de las mujeres y hacer visible una serie de cuestiones sociales con impacto directo en sus vidas. Este ensayo entreteje un conjunto de reflexiones sobre algunos de los rasgos específicos de la intervención que pueden iluminar cómo y por qué esta nueva marea feminista ha conseguido tanto ímpetu mientras redefine lo que entendemos por activismo. Inspirado en las nociones de Judith Butler sobre el potencial político performativo de la asamblea (Notes Toward a Performative Theory of Assembly, 2015), este ensayo revela las distintas formas de resistencia encarnada en los cuerpos de esta nueva ola de activistas que ocuparon el espacio público, la así llamada "marea verde" por el color que identifica a la Campaña por el Aborto Legal, Seguro y Gratuito. Al reclamar un espacio performativo único y radical en el que para ejercer la agencia y desplegar nuevas formas de organización, la "marea verde" ha conseguido reclamar al mismo tiempo una reconfiguración del espacio público que conduzca a nuevas formas de sociabilidad y a la preservación de todas las vidas.

Palabras clave: Marea verde; Campaña por el Aborto Legal, Seguro y Gratuito; Performance colectiva; Activismo. 


\section{INTRODUCTION}

$\mathrm{O}$ n July 31, 2018, Buenos Aires's subway system was overtaken by a public intervention co-organized by Ni Una Menos - a feminist social movement focused on gender violence - , the Campaign for the Right to Legal, Safe, and Free Abortion, unionized metro workers, and more than 70 organizations, with the overall intention of calling attention to a series of social issues with direct impact on women's lives. This massive takeover of the six lines that make up the subway system of Argentina's capital city was both prompted by and largely centered on the legalization of abortion; accordingly, the intervention explicitly included not only women in its appeal but also every person with the capacity to gestate. The project to legalize abortion had been voted on in Cámara de Diputados (the Lower Chamber) on June 13, resulting in 129 votes for and 121 votes against legalization after a marathon 23-hour session. During several consecutive weeks following what turned out to be one of the largest mobilizations in the country - a vigil of 1,000,000 people outside the Congress building - , feminists assembled every Tuesday to collectively discuss strategies in preparation for the debate in Cámara de Senadores (the Upper Chamber) scheduled for August 8. The last "Martes Verde" (Green Tuesday), named after the color identifying the Campaign for the Right to Legal, Safe, and Free Abortion and adopted in turn by the movement Ni Una Menos, was devoted to Operación Araña (Operation Spider), the subway intervention on July 31.

This study weaves a series of critical reflections on some of the specific features of the Operación Araña intervention that can shed light on how the category of gender is mobilized anew in some of the present and ongoing iterations of the feminist movement in Argentina. While the dynamic between the theoretical production of knowledge within academic settings and militant feminism is not something new in Argentina and other Latin American countries, the novelty is that it is the younger generation — sometimes even of high school age — that has taken to the streets while demanding an inter-generational conversation around Gender Studies. The flash mob organized by the Chilean feminist collective Lastesis in Santiago de Chile this past November - "Un violador en tu camino" (A rapist in your path) — is only one of many examples of activists that acknowledge drawing inspiration from a particular gender theory or thesis - hence the name. In response to the alarming number of sexual assault crimes perpetrated by Chilean policemen against young female activists during the protests against Sebastián Piñera's government, Lastesis resorted to anthropologist Rita Segato's (2010) theorizations around gender violence to inspire the lyrics and steps of a performance that has traveled far and wide all over the world. As will become clearer later, Operación Araña was also an intervention spurred by socio-economic conditions brought about by harsh 
neoliberal governments, and, like Un violador en tu camino, it helped expose and condemn violence. The broad and multi-layered engagement of Operación Araña with gender violence not only invites us to revisit Judith Butler's theories on the performativity potential of the assembly but also, and most importantly, helps us establish a bridge with other, newer theories more concerned with the intersection of material and discursive practices.

The first large-scale march under the motto/hashtag \#NiUnaMenos took place in Buenos Aires and several other cities in Argentina on June 3, 2015, in response to the brutal assassination of fourteen-year-old pregnant Chiara Páez by her sixteen-year-old boyfriend Manuel Mansilla. Other marches followed on the same day during 2016, 2017, and 2018, under the slogans "\#VivasNosQueremos" (We want to Live), "Basta de femicidios: el gobierno es responsable" (No More Femicides: the Government is Responsible), and "Sin \#AbortoLegal no hay \#NiUnaMenos. No al pacto de Macri con el FMI" (Without \#LegalAbortion There is no \#NiUnaMenos. No to Macri's Pact with the IMF). The gradual change in name of the slogans guiding each one of the marches betrays the existence of a movement that is constantly adapting as it moves away from an exclusive focus on femicides to a much broader agenda that at the time of the Operación Araña intervention even included specific demands to Argentina's former president, Mauricio Macri. This new wave of feminists sees abortion, femicides, and austerity measures as different but interrelated forms of violence toward women and bodies marked as feminine. The "marea verde" (green tide), as it has come to be popularly called, has proved to be a movement surging and enveloping in its energy an unprecedented number of supporters, some of whom have never had any previous militant experience. This is the undertow that made the earth tremble on July 31 . This is the undercurrent that will be unpacked in this work through an examination of Operación Araña's movement toward new, innovative, and radical ways of understanding and occupying public space.

\section{THE EARTH TREMBLES: THE IMPACT OF NEOLIBERALISM AND THE OPERACIÓN ARAÑA INTERVENTION}

$\mathrm{T}$ he name of the overpowering massive public intervention on July 31 itself points to both an agenda and resources to put that agenda into action, which include but are not limited to the single issue of abortion. As if spinning a web, the organizers of Operación Araña threaded the entire city by assigning one social issue — " una línea de conflicto" (a line of conflict) — to each subway line, sustaining the entire structure with a community of collective care and support that nourished every action staged throughout that day. 


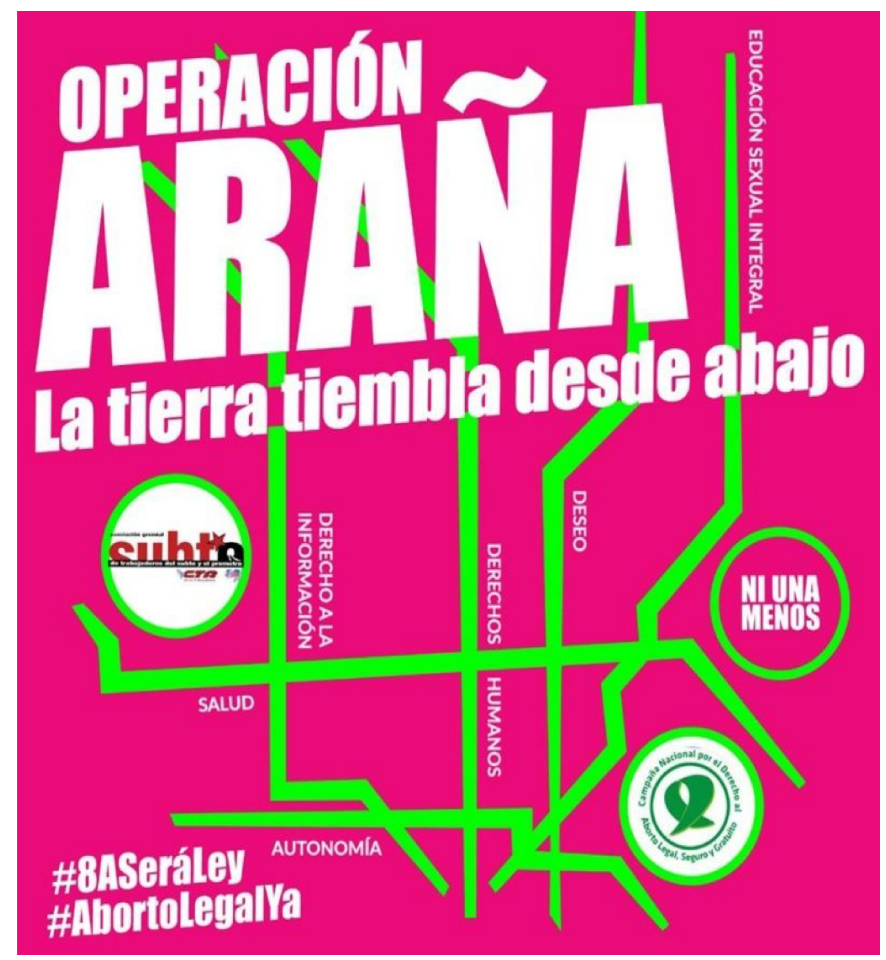

Figure 1 - Information Poster for Operación Araña. Source: Lobo Solto!, 2018.

The emphasis placed on the need for a community web was made explicit in metro line C, as activists on that line situated the demand for autonomy over one's body within a collectivity of community bonds and support networks and as the continuation of a struggle fought by other women in other times and other territories. Part of the official statement read out loud by organizers on the line C trains declared: "We do not demand a separate individual's autonomy, but an autonomy that unfolds as common desire" (Lobo Suelto!, 2018). As to the other lines, while metro line A feminists focused on abortion as a human right to decide over one's own body, those on metro line $\mathrm{H}$ approached it as a public health concern. Questioning motherhood as a social mandate, the intervention performed on metro line B advocated for motherhood as a choice and a desire, aided by the hashtags "\#LaMaternidadSeráDeseadaONoSerá" (Motherhood will be desired or won't be) and "\#NosMueveEIDeseo" (Desire Moves Us). On metro line $\mathrm{E}$, a demand was articulated in favor of access to the information necessary to decide over one's body in the face of widespread oppressive misinformation, and activists on line D called for the application of the Law for Educación Sexual Integral (ESI: Comprehensive Sex Education) in all schools. True to its spirit of taking over and redefining categories, 
concepts, and spaces, Operación Araña re-appropriated the slogan used by the National Campaign for Abortion, "Educación sexual para decidir, anticonceptivos para no abortar, aborto legal para no morir" (Sex education to decide, contraceptives to avoid abortion, legal abortion not to die), transforming it into "Educación sexual para descubrir, anticonceptivos para disfrutar, aborto legal para decidir en libertad y para hacer un mundo habitable para todes" 1 (Sex education to discover, contraceptives to enjoy, legal abortion to decide freely and build a world inhabitable by everyone). Invoking the power of community bonds to help exercise one's freedom joyously - the different interventions in the six metro lines were marked by music and dancing - in an inclusive and welcoming world, the spiders wove multiple demands into one single massive web that centered on reclaiming ownership of bodies, territories, and bodies as territories.

The Law for Voluntary Pregnancy Interruption (Ley de interrupción voluntaria del embarazo) did not pass in the Upper Chamber on August 8, by a narrow margin, and in the next week or so, at least two more women died from complications derived from an abortion performed clandestinely ${ }^{2}$. The activists who had staged Operación Araña, those selfsame activists who had once more camped out outside Congress to follow the debate inside the building hour by hour, minute by minute, were quick to raise an outcry: "A death by clandestine abortion is a state femicide" (Lobo Suelto!, 2018). Both femicides and deaths by abortion are viewed by these activists as violent acts perpetrated against feminized bodies by a state largely responsible for these and other forms of gender violence, either via neglect or by implementing austerity measures whose effects are disproportionately harsher on these bodies. Labor exploitation, salary reduction, job insecurity, massive layoffs, budget cuts, police violence, the criminalization of sexual dissidence, the uninhibited exploitation of common resources, among others, are all but manifestations of neoliberal regimes that have taken over Latin American countries since the 1990s. ${ }^{3}$ Judith Butler's words describing the biopolitical situation wherein large populations are subject to "precaritization" seem apt here to explain reigning conditions in Argentina today:

Usually induced and reproduced by governmental and economic institutions, this process acclimatizes populations over time to insecurity and hopelessness; it is structured into the institutions of temporary labor and decimated social services and the general attrition of the active remnants of social democracy in favor of entrepreneurial modalities supported by fierce ideologies of individual responsibility and the obligation to maximize one's own market value as the ultimate aim in life (Butler, 2015: 15).

In the face of precaritization, this new wave of Argentinean feminists resists insecurity and hopelessness by forming bonds transversally with other groups propelled by the "insight 
that this is a social condition both shared and unjust" (Butler, 2015: 16). Several unionized workers, for instance, have defied their union leaders and participated in the so-called "pañuelazos," or actions with "pañuelos," the green kerchiefs flooding every single march, protest, or demonstration around the issue of abortion. In turn, unionized women workers have adopted methods of struggle launched by the green tide. Conversely, the new wave of feminist activism has become a visible and constant presence in several labor conflicts. Ni Una Menos assemblies have been organized by workers laid off from the multinational corporation PepsiCo and the Télam national news agency, as well as by women from Mapuche indigenous communities in Southern Argentina, criminalized by corporations like Benetton, which control most of the land in the region.

"The tide thinks the abortion debate in direct relationship to the economy," summarizes Cecilia Palmeiro (2018), one of the leading voices of the Ni Una Menos movement, as she links the problem of clandestine abortions to larger social, economic, and political issues. Both the mobilizations prompted by the debate around the legalization of abortion and the series of strikes organized have been informed by a profound sense of class consciousness, as activists addressed differentiated possibilities of access to safe abortion and forms of labor that remain invisible and unrecognized. In their interview with Jacobin magazine, Luci Cavallero et al. (2018) strongly state:

Women are half of the working class, we are the majority of teachers and nurses, we have the majority of the precarious jobs, and we perform the overwhelming majority of reproductive work at home. This is why a basic right, such as the freedom to decide about one's own body, to decide on motherhood, is a right for which the entire working class has to fight. Similarly, that is why the precariousness of work, the lack of funds for health and education (which took the lives of two teachers last week), the extension of the working day (which makes the double burden of housework and paid work unbearable), and all these attacks on the working class have to be demands of the feminist movement.

Drawing a close connection between femicides and other forms of gender violence, the major feminist strike convened around March 8 - International Women's Day — during the past couple of years has exposed institutional and economic violence as it expands and redefines the notion of work and its value, foregrounding precaritization as a common condition. In so doing, the strike makes visible the demands of workers within the popular economy sector, like trash pickers, metro workers, neighborhood soup kitchen aides, telephone operators of the 144 hotline for cases of gender violence, among others ${ }^{4}$. Organizers have also emphasized how women and feminized individuals are the ones typically suffering the most direct and brutal hit of economic measures, repeatedly alluding to the "feminization of poverty." 
Argentina's loan from the International Monetary Fund under Mauricio Macri's administration brought about extreme austerity measures whose effects were felt by feminist activists on their own bodies. The feeling of long-term indebtedness at a national, public level was closely aligned with their private, individual indebtedness as they found themselves unable to lead debt-free, dignified lives. Their bodies felt indebted, much like the territories sold to foreign multinational companies to plunder freely and limitlessly. Such a perception ostensibly lies at the foundation of the demand powerfully expressed by Marcha de Mujeres Originarias (March of Native Women) as they looked ahead to the Ni Una Menos protest on June 3, 2018 :

Para nosotras en el 3 de junio tienen que aparecer por lo menos 3 palabras que son: Feminicidio, Judicialización y Plurinacional. Feminicidio porque es el Estado el que nos mata, nos oprime, el que abandona los territorios junto con las mujeres y los niños, entrengándolos a los grandes empresarios por el megaextractivismo, por la deforestación [...]. Judicialización: por todas las causas que se le arman a las hermanas en los territorios, por defensa de los territorios, por defender los lagos, las montañas, las vidas, las hermanas terminan siendo judicializadas. Plurinacional porque en este Estado estamos totalmente invisibilizadas [...] queremos que el Ecuentro de Mujeres sea plurinacional, que seamos respetadas desde nuestra espiritualidad, nuestra lengua, nuestra cosmovisión (Paz Frontera, 2018, italics and bold in the original).

For us, on June 3, at least 3 words need to appear: Femicide, Prosecution, and Plurinational $^{5}$ Femicide because it is the State that kills us, oppresses us, abandons our territories alongside women and children, giving them away to important business people on account of megaextractivism, deforestation [...]. Prosecution for all the lawsuits filed against our sisters in our territories, for defending these territories, for defending lakes, mountains, lives, our sisters end up being sued. Plurinational because for the State, we are completely invisible [...] we want the National Meeting of Women to be plurinational, [we want] to be respected in our spirituality, our language, our world view (Paz Frontera, 2018, italics and bold in the original).

The article that articulates these demands bears testimony to a movement that is trying to be inclusive of a wide variety of voices. Besides representatives from the Campaign for the Right to Legal, Safe, and Free Abortion, Ni Una Menos, and various political parties, Agustina Paz Frontera (2018) interviewed Lara María Bertolini, a travesti activist, Sabrina Montenegro, an activist for Asamblea Lésbica Permanente (Permanent Lesbian Assembly), and Georgina Orellano, the Secretary for the Argentinean Association of Sex Workers (Asociación de Mujeres Meretrices de la Argentina - AMMAR), among others, who made a point of mentioning additional demands like the "cupo laboral trans" (hiring quota for trans people), an end to the criminalization of non-binary identified individuals, and sustained legal action to protect sexual dissidence. 
In response to the disappointing vote against the legalization of abortion on August 8, Cavallero et al. (2018) declare: "We will continue to expose how the issue of abortion intersects with other social problems such as work, poverty, and racism". In a country that has been historically blind to racial justice issues ${ }^{6}$, such an acknowledgment at the very least signals to a future in which, as the two activists hope, class struggle will not just be indexed to male, white, heterosexual (Cavallero et al., 2018). Throughout their interview, Cavallero et al. (2018) focus largely on class issues in order to delineate this new feminism as predominantly anticapitalist, and it is indeed this class awareness that informs the activists' frequent references to "transversality." It remains yet to be seen how truly intersectional the movement becomes as it has started gesturing toward explicitly including Afro-Latinas and indigenous women in its demands. As the Mapuche leader Maitén Cañicul Quilaleo cautions, despite efforts to create a truly peripheral, popular, indigenous feminism, tension across class and race is still prevalent: "En estos terrenos se generan contradicciones grossas, como por ejemplo, la patrona feminista que sale a marchar y la doña que le cuida los hijos. Mujer Mapuche desterrada de su territorio, le cuida los hijos para que pueda marchar" (These areas present huge contradictions, for example, the feminist employer that takes to the streets to protest and the maid who looks after her children. The Mapuche woman banished from her territory watches her employer's kids so that she can protest) (Moyano, 2018). For now, it bears pointing out in this respect that, whereas the first images circulating on social media in connection with the Ni Una Menos movement, even on their website, consisted mostly of cisgender white heterosexual women, the page has now diversified to include a wider array of demands and a more heterogeneous base. This change, together with the article above-mentioned and the images of the marches circulating today, can be a sign that the movement keeps evolving, aware of its urgent need to become truly intersectional.

The connection between bodies and territories is one that Afro-indigenous women explicitly articulate as they emphasize their forced displacement from their territories and the extractivist urge depleting all of the natural resources they depended upon for their survival. Nevertheless, it is a connection that the green tide, in general, has come to voice more and more overtly as they expand their notion of violence to consider multiple intersecting factors. In essence, this new cohort of feminists has come to a full embodied understanding of the "differential distribution of precariousness," that is, "precarity" as Butler (2015: 33) defines it: "The politically induced condition in which certain populations suffer from failing social and economic networks of support more than others, and become differentially exposed to injury, violence, and death." The activists taking to the streets in all these marches have managed to express collectively their extreme vulnerability and how this vulnerability translates into extreme forms of state, judicial, police, and domestic violence. Their bodies have spoken like never before, and not only through megaphones and via slogans and hashtags written on 
banners, headscarves, flags, and fliers. The collective embodied actions of Operación Araña, like so many other interventions carried out by Ni Una Menos, say more loudly than ever that they refuse to stay passive in the face of outright violence. Their bodies are ever more aware of the indissociable ties between the pillaging of territories, the exploitation of labor, and the violence against feminized bodies. As feminist anthropologist Rita Segato (2010) powerfully argues, the interrelatedness of these various forms of abuse even manifests itself in the etymological origins of the terms describing them: "Let us not forget that rapiña, the Spanish word for pillage, and rapinagem, the Portuguese word for voracious looting, share a root with rape" (Segato, 2010, 87, 2018, italics in the original). On their official statement on the eve of the Senate vote on August 8, Ni Una Menos activists unabashedly pointed to the responsibility of the Catholic Church in complicity with the State for stalling the decision to legalize abortion, and they end with the call: "Criminalization, indebtedness, and blame placed on our bodies and territories." The official statement issued by Operación Araña seems to have preemptively provided a response for such a call on July 31, as it concluded with these words:

Tomamos la ciudad en red y en movimiento y lo mezclamos todo porque las tramas de las violencias afectan nuestras vidas de manera compleja y simultánea. El aborto clandestino no puede pensarse por fuera de esas violencias. La ciudad feminista es un cuerpo colectivo que activamos entre todas y que nos permite reapropiarnos de nuestros cuerpos que son nuestros territorios (We are taking the city as a web in motion and mixing everything up because the threads of violence affect our lives in complex and simultaneous ways. Clandestine abortion cannot be thought of outside these forms of violence. The feminist city is a collective body we all activate together, allowing us to reappropriate our bodies, which are our territories) (Lobo Suelto!, 2018).

The bodies of the green tide are flooding the streets, the metro lines, the main squares, even the schools and the workplaces; they are bodies on the line refusing to be raped and pillaged.

\section{BURNING BODIES OUT OF HIDING}

$\mathrm{N}$

i Una Menos's statement above mentioned starts by issuing a warning, so to speak: "We are already preparing, bodies are already burning in the middle of winter, we know who will be in the streets with us to defend our right to make decisions about our bodies and our lives" Ni Una Menos started as a collective outcry against femicides; from the start, its demands have been displayed on the bodies, or bodies conceived as surfaces/territories upon which gender violence is enacted. Operación Araña's web revealed, as it were, the nervous system of that city being redefined as a feminist collective body, each line a nerve, a blood vessel, as feminist scholar Marie Bardet (2018) beautifully articulates in her piece "Política 
de las arañas y las redes:" "cada línea como un filón nervioso, afectivo político de nuestra cuerpa ${ }^{7}$ colectiva" (each line a nervous, affective, and political filament of our collective body) (2018). These bodies claim the political through their potential for expression, and this potential is actualized in a speaking-with, an embodied dialogue in the way Erin Manning (2007) poses it, located in "the porous skins of our intermingled and overlapping bodies" (Manning, 2007: 116). The bodies that mingled with passengers on the metro lines on July 31 reached out to one another, to others, and to the spaces of the subway that were open and willing to know and be known differently. "If new bodies are what is at stake, new politics will have to be created," Manning (2007: 131) summarizes. The bodies of the spiders were bodies armed with megaphones, with brochures debunking myths about abortion, glittered bodies in green singing and dancing and rapping and waving kerchiefs in and through joyous movement wherein their senses, like the multiple props they carried, could "be considered as techne, technologies (or prostheses) of the moving body" (Manning, 2007: 117, italics in the original). There were no boundaries to these unstoppable bodies as they left traces of themselves everywhere.

This "devenir arácnido" (arachnid becoming), as Bardet (2018) calls it, enables gestures, actions, modes of being that "escapan al 'yo quiero' voluntario y racional como vivibles" (escape the voluntary and rational "I want" as livable). In order to fully understand the freedom claimed by these bodies unconstrained by the individualized market value placed upon them by a violent neoliberal agenda, it seems pertinent to remember Manning's (2007: 125) words on liberty:

Liberty, then, not as a power to be an individual, but as an emergent force to individuate. Liberty as a sharing of movement that is a reaching toward. Sharing as a participation in a spacing through which timed-spaces and spaced-times are created and passed through. Sharing as the experience of two bodies touching, creating spacings through which they surprise themselves, again and again.

The unexpected, surprising spaces created and nourished by these bodies through their collective political performativity upset the neoliberal notion of individual responsibility as they generated shared plural actions that not only demanded better living conditions for everyone but also staged those selfsame conditions. Herein lies the expressive political possibility of embodied collective action, as Judith Butler lucidly outlines: "Showing up, standing, breathing, moving, standing still, speech, and silence are all aspects of a sudden assembly, an unforeseen form of political performativity that puts livable life at the forefront of politics" (Butler, 2015: 18). As the bodies of Operación Araña assembled in the metro stations, and as they took their assemblies out into the streets and the main squares, they defied the conditions that tradi- 
tionally regulate their appearance in the public sphere, insisting with their embodied presence on their right to be there.

Femicides started off Ni Una Menos; let us not forget that. Whereas a large number of these crimes occur inside the domestic intimacy of the private sphere, the Argentinean media has consistently given prominence to those incidents that involve women and individuals marked as feminine circulating in public spaces considered to be off-limits. Crimes of the former type tend to be justified by attributing them to "passion"," while the latter ones are rationalized via references to the fact that the victim was circulating in a deserted, unlit area, a space "unsafe" for women. Operación Araña overturned this narrative and questioned its legitimacy. By taking to the public space unrestrained and uninhibited, the spiders set in motion an embodied enactment of their right to move freely through the city, no matter how deserted, no matter how dark, no matter the circumstances. In so doing, they also radically changed the conditions that set the terms on how their bodies should appear, in what ways they could get around the city. These activists claimed their own right to move and travel (in) the public space without the threat of violence that they have grown and been taught to fear. Most importantly, they laid claim to that right by acting it out, and they acted it out, in Operación Araña and other interventions, in ways that subverted gender expectations. One of the most hotly debated interventions, for instance, was staged in response to three topless women expelled from the beach at the seaside town of Necochea. Called "tetazo," from "teta" (boob), the action staged on February 7, 2017, consisted of topless women gathering at the Obelisk in Buenos Aires, a national iconic historical monument where two of the busiest streets of the capital city intersect, sparking rage and offending a large part of the population. Like the spiders on July 31 , the activists staging the "tetazo," claimed their right to embody their gender and act their sexuality as they pleased, not as the Church or the State mandated.

The sovereignty over their bodies, their right to decide on abortion, motherhood, and sexuality, threaded together all nervous filaments of that collective body created by Operación Araña. It is sovereignty, as Luci Cavallero et al. (2018) declared, that "is not an individual question, but lies at the intersection of interdependence and the precarization [sic] of our existence." In "The Fire is Ours," the official Ni Una Menos statement released on August 7, the organizers exercised their right to occupy the public space freely when they announced the actions to be taken if the Law for Voluntary Pregnancy Interruption did not pass: "We have brought our bodies, our abortions, and our desires out of hiding, and we will not go back" (Ni Una Menos, 2018). In reality, this new wave of feminists was already exercising this right performatively the moment they took to the streets, on the eve of the Senate's vote, as they staged a vigil that, according to Palmeiro (2018), " resembled a festival and a coven." In a manner similar to the demonstrations in Tahrir Square analyzed by Butler (2015: 90), the vigils 
staged by around 1,000,000 people both times the law was being debated were powerful political statements "breaking down a distinction between private and public," with activists setting up feeding and sleeping arrangements alongside activities organized to keep everyone's spirits up while putting pressure on Congress members. The vigils were also, and above all, not just about the debate inside the Chambers; the bodies keeping vigil were demanding to be recognized and valued in their right to appear and to live freely and unaffected by precariousness. By being right then and there, they were also making evident how the public sphere is constituted by recognizing some bodies and misrecognizing, or outright obliterating, others. Recognition and effacement are traversed by class, ethnicity, and gender when it comes to the operations whereby the public space acquires its status. Therefore, by appearing, and doing so often and insistently, the bodies expose the restrictive ways in which the public sphere is posited. "The struggle," in Butler's words, then "becomes an embodied one for recognizability, a public insistence on existing and mattering," and that is precisely what the Mapuche women alluded to earlier have adopted as their strategy (Butler, 2015: 37).

\section{THE PLURAL, RECONFIGURED SPACES OF THE ASSEMBLIES}

(1 The very public character of the space is being disputed, and even fought over, when these crowds gather," states Butler (2015: 71). It has already been revealed how the actions of Ni Una Menos activists have established coalitions transversally among women from various social classes and across various spaces that go beyond Plaza de Mayo — the Square in front of the Casa Rosada building where the president's offices are located. Operación Araña's unique intervention in the subway system was the corollary of multiple previous interventions in the streets, community centers, workspaces, and high schools where students have been mobilizing, constituting one of the largest groups making up this new feminist wave. Another dimension to this spatial intervention should be added, however, as every intervention also spawned a reconfiguration of the materiality of all those public spaces where an embodied collective action happened. In all those locations, camaraderie overflowed in a shared, common affirmation of the right to have rights and exercise these rights joyously in an unhindered manner. The bodies decked out in green boas and kerchiefs, green glitter makeup, nail polish, and lipstick, signaling their alliance, seized and reconfigured the physical space of the urban landscape to stage, once again, their right to be there. The material environment was part of their performative exercise, and it also, in turn, defined and supported their actions, shaping them and making them happen. Conversely, the material history of the physical spaces where bodies deployed their actions bore heavily upon those actions. The history of Plaza de Mayo will in this sense suffice as an example, as it is the foundational site of the city 
of Buenos Aires, and, like most main squares in Latin American countries, has both witnessed key moments in the country's history - like the independence from colonial rule (1816) or the return of democracy after a seven-year dictatorship (1976-1983) — and served as the stage for numerous massive demonstrations and protests during periods of intense social and political turmoil. Plaza de Mayo is also the place where the Mothers of Plaza de Mayo have marched every Thursday since 1977 to demand answers about their disappeared children ${ }^{9}$. In the interaction between embodied collective action and the newly reconfigured physical space, "a new space is created, a new 'between' of bodies, as it were, that lays claim to existing space through the action of a new alliance, and those bodies are seized and animated by those existing spaces in the very acts by which they reclaim and resignify their meanings" (Butler, 2015: 85). The new spaces created also produced and were produced by forms of gathering and organization intent on generating new practices of resistance and more plural alliances.

In preparation for Operación Araña, as in the case of the vigils, marches, and other demonstrations organized by Ni Una Menos, this new wave of feminists engaged in debates, encounters, and assemblies to discuss the interconnected forms of violence to be fought against and plan steps for future political actions. In their plurality, non-hierarchical arrangement, and various collaborative stages, the green tide was wielding the strategies and techniques for the new form of social organization and the reorganization of social life that its own performative collective actions demanded. Their assemblies alone were the actions, and they became a crucial organizational tool for each one of the Ni Una Menos interventions. It is this power of the assembly to remap the act of protesting in general that Verónica Gago (2018) has in mind when she describes one of the three important dimensions of the strikes organized, namely, an emphasis on the strike as a process rather than an event. She states: "This means concretely producing the time of the strike as a time of organization, of conversation, of building a common web, of coordination in assembly, of bringing subjectivations into play that elaborate a new type of radicality" (Gago, 2018: 663). This community web is what Ni Una Menos invokes in the official statement mentioned earlier for feminists to be able to conceive of autonomy as something other than an equation of the individual body with private property. It is the "devenir arácnido" invoked in turn by Marie Bardet (2018), a becoming or transformation that informs decisions, gestures, desires, imaginings, always performed collectively, "to live and develop ourselves, to collectively care for each other" ("The Fire is Ours"). New forms of sociality are engendered, and they are also but go beyond forms of organization, disarming and questioning the neoliberal "entrepreneurial ethic that exhorts even the most powerless to take responsibility for their own lives without depending on anyone or anything else" (Butler, 2015: 67). Instead, 
sorority, interdependence, and solidarity among this new generation of feminists create a web that is giving rise to an invigorated radical, mass feminist movement, "one capable of theorizing and acting from below," like the spiders weaving the Operación Araña intervention (Cavallero et al., 2018).

\section{"LAS PIBAS" AND THE GREEN TIDE: TOWARD THE FUTURE}

$\mathrm{T}$ he main protagonists of the green tide have indeed been "las pibas," the teenage feminists who have staged assemblies in their own schools and organized mobilizations, oftentimes defying institutional rules, confronting principals, and risking reprimand. The term itself by which they are commonly referred in everyday language, "pibas," in its slang register, signals to the popular nature of a movement that remained for them until recently alien, stale, distant. This new public, popular, collective feminism is truly intergenerational, uniting these teenagers with older activists, the feminists that started to fight for abortion in the 1990s. It is perhaps this unique convergence of older but still relevant demands, with newer forms of political performativity, that is yielding a "feminism from below that has recreated the feminist perspective from the South," as Mariana Menéndez Díaz and Liz Mason-Deese (2018: 697) argue in their reflection around the March 8 strike in Montevideo, Uruguay. The Earth is trembling in the South, and the tremors are being felt throughout Latin America, where more and more women and individuals marked as feminine are reconstructing social relations "beyond traditional feminist positions" (Gutiérrez Aguilar and Mason-Deese, 2018: 677). "We feel internationalism as part of our core political identity," declare Camila Barón and Gabriela Mitidieri (apud Cavallero et al., 2018). An internationalist, intergenerational, intersectional, transversal, public feminism from below is shattering the foundations of a patriarchal system that until recently seemed unbreakable, and it is doing so joyously, amorously, freely, like the spiders of the Operación Araña singular intervention.

\section{NOTES}

1 The pronoun "todes" (everyone) is currently being used in Argentina and other Latin American countries, especially among feminists, to signal inclusivity of all genders, as opposed to the generic "todos", which is grammatically marked as masculine.

2 During one of the informative sessions in Congress that debated the legalization of abortion, the Minister of Health himself recognized that 354,627 abortions are performed illegally in the country every year. Around 70,200 women need to be hospitalized on account of com- 
plications derived from the unsafe conditions wherein clandestine abortions are performed. Most of the time, it turns out to be too late to save these women from dying once they get to the hospital (Hayon, 2018).

3 Several post-dictatorship Latin American societies in the 1990s were traversed by austerity measures resulting in a displacement of the central role of the State to give free rein to foreign investment and a free market economy. After the economic collapse of 2001, Argentina had a succession of four interim presidents in the course of a year. In 2003, the peronista candidate Néstor Kirchner won the election, inaugurating the so-called "kirchnerista era" in the country, as he was succeeded in the presidency by his wife Cristina Fernández de Kirchner, who occupied the presidency between 2007 and 2015. Broadly speaking, the "kirchnerista era" was characterized by a gradual economic recovery, especially in its first few years, a decrease in poverty and unemployment levels, and sustained concern to prevent human rights abuses. From 2015 to 2019, under president Mauricio Macri, the country reverted to neoliberal policies reminiscent of the 1990s. Even though president Alberto Fernández, who took office on December 10 of last year, is aligned with kirchnerismo — the vice president is actually Cristina Fernández de Kirchner — , it is still too soon to assess the extent to which his government will be capable of addressing the extreme poverty and unemployment, as well as consequent widespread social inequalities left in the wake of Macri's presidency.

4 In their interview with Jacobin magazine, Luci Cavallero et al. relate a very specific action connected to the strike that illustrates this point well: "On June 2 of last year, we carried out an action in front of the Central Bank denouncing the financial capital control over domestic economies, particularly over households where women provide the principal income. The action was \#DeseundadasNosQueremos (We Want Ourselves Debt Free)" (Cavallero et al., 2018).

$\mathbf{5}$ The term "Estado Plurinacional" in Latin America is used to signal the inclusion within the State of all native indigenous populations, or "nations."

6 See, for instance, the Report Towards a National Plan against Discrimination: Discrimination in Argentina; Diagnosis and Proposals coordinated by Waldo Villalpando (2005) with the collaboration of experts Daniel Feierstein, Norma Fernández, Ana González, Horacio Ravenna, and María Sonderéguer.

7 The term "cuerpo" (body) is always masculine in Spanish; some feminists are opting to mark it as feminine as a political statement in line with the use of an inclusive language (See Note ii above). 
8 For an interdisciplinary approach to gender violence in different contexts and spaces, see Violencia contra las mujeres: La subversion de los discursos (Colanzi et al. 2017).

9 See, for instance, Revolutionizing motherhood: the mothers of the Plaza de Mayo, by Marguerite Bouvard Guzman (1994).

\section{REFERENCES}

BARDET, M. Política de las arañas y las redes. Lobo suelto! Anarquía coronada, 2018. Available from: <http:// lobosuelto.com/politica-de-las-aranas-y-las-redes-marie-bardet/>. Accessed on: Sept. 10, 2018.

BOUVARD GUZMAN, M. Revolutionizing motherhood: the mothers of the Plaza de Mayo. Wilmington: Scholarly Resources, 1994.

BUTLER, J. Notes Towards a Performative Theory of Assembly. Cambridge: Harvard University Press, 2015.

CAVAlLERO, L.; GAGO, V.; VARELA, P.; BARÓN, C.; MITIDIERI, G. 2018. "Argentina's Anticapitalist Feminism," interview by Cinzia Arruzza and Tithi Batthacharya. Jacobin, 2018. Available from: <https://www.jacobinmag. com/2018/09/argentinas-anticapitalist-feminism>. Accessed on: Sept. 15, 2018.

COLANZI, I.; FEMENÍAS, M. L.; SEOANE, V. (orgs.). Violencia contra las mujeres: La subversión de los discursos. Rosario: Prohistoria, 2017.

GAGO, Verónica. \#WeStrike: Notes Toward a Political Theory of the Feminist Strike. South Atlantic Quarterly, v. 117, n. 3, p. 660-669, 2018. https://doi.org/10.1215/00382876-6942233

GUTIÉRREZ AGUILAR, R.; MASON-DEESE, L. Women's Struggle Against All Violence in Mexico: Gathering Fragments to Find Meaning. South Atlantic Quarterly, v. 117, n. 3, 670-681, 2018. https://doi. org/10.1215/00382876-6942245

HAYON, A. Otra muerte por aborto clandestino. Página/12, 2018. Available from: <https://www.pagina12. com.ar/135195-otra-muerte-por-un-aborto-clandestino>. Accessed on: Aug. 18, 2018.

LOBO SUELTO! Operación Araña. La tierra tiembla desde abajo // Comunicado. Lobo suelto! Anarquía Coronada, 2018. Available from: <http://lobosuelto.com/?p=20629>. Accessed on: Sept. 12, 2018.

MANNING, E. Politics of Touch: Sense, Movement, Sovereignty. Minneapolis: University of Minnesota Press, 2007.

MENÉNDEZ DÍAZ, M.; MASON-DEESE, L. March 8: Between the Event and the Webs. South Atlantic Quarterly, v. 117, n. 3, p. 692-698, 2018. https://doi.org/10.1215/00382876-6942269

MOYANO, A. No está bueno un movimiento feminista que se defina sin nosotras. Enestosdías: El contexto es la noticia, 2018.

NI UNA MENOS. The Fire is Ours: Statement from Ni Una Menos. Translated by Liz Mason-Deese. Verso, 2018.

PALMEIRO, C. The Latin American Green Tide: Desire and Feminist Transversality. Interventions and notes from the field. Journal of Latin American Cultural Studies, v. 27, n. 4, p. 561-564, 2018. https://doi.org/10.1080/ 13569325.2018.1561429 
PAZ FRONTERA, Agustina. 2018. Hacia un nuevo Ni Una Menos. LATFEM Periodismo Feminista, 2018. Available from: <http://latfem.org/hacia-un-nuevo-ni-una-menos/>. Accessed on: Sept. 21, 2018.

SEGATO, R. L. Territory, Sovereignty, and Crimes of the Second State: The Writing on the Body of Murdered Women. In: FREGOSO, R.-L.; BEJARANO, C. (orgs.). Theorizing Women: Feminicide in the Américas. Durham: Duke University Press, 2010. p. 70-92.

VILLALPANDO, W. (org.). Towards a National Plan against Discrimination: Discrimination in Argentina; Diagnosis and Proposals. Buenos Aires: INADI, 2005. 